\title{
Late Ordovician (Katian) spores in Sweden: oldest land plant remains from Baltica
}

\author{
AHMED SALAH BADAWY ${ }^{1}$, KRISTINA MEHLQVIST ${ }^{2}$, VIVI VAJDA ${ }^{2}$, PER AHLBERG $^{2}$ and \\ MIKAEL CALNER ${ }^{2}$
}

Badawy, A.S., Mehlqvist, K., Vajda, V., Ahlberg, P. \& Calner, M., 2014: Late Ordovician (Katian) spores in Sweden: oldest land plant remains from Baltica. GFF, Vol. 136 (Pt. 1, March), pp. 16-21. C) Geologiska Föreningen. doi: http://dx. doi.org/10.1080/11035897.2014.899266.

\begin{abstract}
A palynological study of the Ordovician-Silurian boundary (Katian-Rhuddanian) succession in the Röstånga-1 drillcore, southern Sweden, has been performed. The lithology is dominated by mudstone and graptolitic shale, with subordinate limestone, formed in the deeper marine halo of southern Baltica. The palynological assemblages are dominated by marine microfossils, mainly chitinozoans and acritarchs. Sparse but well-preserved cryptospores, including Tetrahedraletes medinensis, Tetrahedraletes grayii and Pseudodyadospora sp., were encountered in the Lindegård Formation (late Katianearly Hirnantian), with the oldest record just above the first appearance of the graptolite species Dicellograptus complanatus. This represents the earliest record of early land plant spores from Sweden and possibly also from Baltica and implies that land plants had migrated to the palaeocontinent Baltica by at least the Late Ordovician.
\end{abstract}

Keywords: stratigraphy; palynology; thermal alteration index; Ordovician; Silurian; Röstånga-1 drillcore; Skåne; Sweden.

${ }^{1}$ Frederikssundsvej 227, 2700 Brфnsh $\phi$, Copenhagen, Denmark; ahmed.salahbadawy@yahoo.com
${ }^{2}$ Department of Geology, Lund University, Sölvegatan 12, SE-22362 Lund, Sweden; kristina.mehlqvist@geol.
lu.se, vivi.vajda@geol.lu.se, per.ahlberg@geol.lu.se, mikael.calner@geol.lu.se
Manuscript received 8 October 2013. Revised manuscript accepted 7 February 2014.

\section{Introduction}

Evidence of early land plant spores have been dated back to at least the Mid-Ordovician (Vavrdová 1990; Strother et al. 1996; Le Hérissé et al. 2007; Rubinstein et al. 2010) and are all from Gondwana, from where they possibly originated (Rubinstein et al. 2010). The earliest known cryptospores are from Middle Ordovician (Dapingian) strata of Argentina (Rubinstein et al. 2010). Other early records include findings from late Darriwilian deposits in the Czech Republic (Vavrdová 1990) and Saudi Arabia (Strother et al. 1996; Le Hérissé et al. 2007). Fragments of the earliest land plants with in situ cryptospores have been described from Oman, and studies of the spore-wall ultrastructure suggest a liverwort affinity for these plants (Wellman et al. 2003). The so far oldest cryptospores described from Baltica are of latest Katian-Hirnantian age from the Valga-10 core in southern Estonia (Vecoli et al. 2011). The dating of these spores, however, is uncertain and the spores described in the present study are slightly older than the spores described from the Valga-10 core. Previous palynological studies from Swedish Palaeozoic successions have identified spores in strata of Silurian age (Wenlock-Pridoli) both from Skåne and Gotland (Gray et al. 1974; Hagström 1997; Hagström \& Mehlqvist 2012; Mehlqvist et al. 2012, 2014).

In this pilot study, the palynology of the Röstånga-1 drillcore has been analysed in order to investigate the occurrence of land plant-derived spores. The Röstånga-1 core was drilled in west- central Skåne (Scania), the southernmost province of Sweden (Fig. 1), and is considered to comprise the stratigraphically most complete Upper Ordovician through lowermost Silurian succession from this area of Sweden (Bergström et al. 1999). Palaeogeographically, this location is within the slowly subsiding cratonward side of the German-Polish Caledonian foreland basin (Fig. 1; the Scanian Confacies Belt of Jaanusson (1995); see Erlström et al. (1997) and Calner et al. (2013) for reviews of the tectonic evolution of Skåne), and the studied succession is therefore relatively thin.

\section{Materials and methods}

The Röstånga-1 core was drilled by Borrbolaget, Västra Frölunda, in 1997 and has previously been studied by Bergström et al. (1999), Pålsson (2002), Koren’ et al. (2003), Bergström et al. (2014) and Maletz et al. (2014). The core has a diameter of $71 \mathrm{~mm}$ down to a depth of $40.13 \mathrm{~m}$, and a diameter of $52 \mathrm{~mm}$ in the interval $40.13-132.59 \mathrm{~m}$. The succession in the core dips $35^{\circ}$. The stratigraphic interval discussed herein corresponds to a depth of 108.84-49.00 $\mathrm{m}$ and comprises, in ascending order, the Skagen Limestone, the Mossen Formation, the Fjäcka Shale, the Lindegård Mudstone and the lowermost part of Kallholn Formation. The lithologies range from dark grey limestone to light grey mudstone and black, organic-rich shale. 


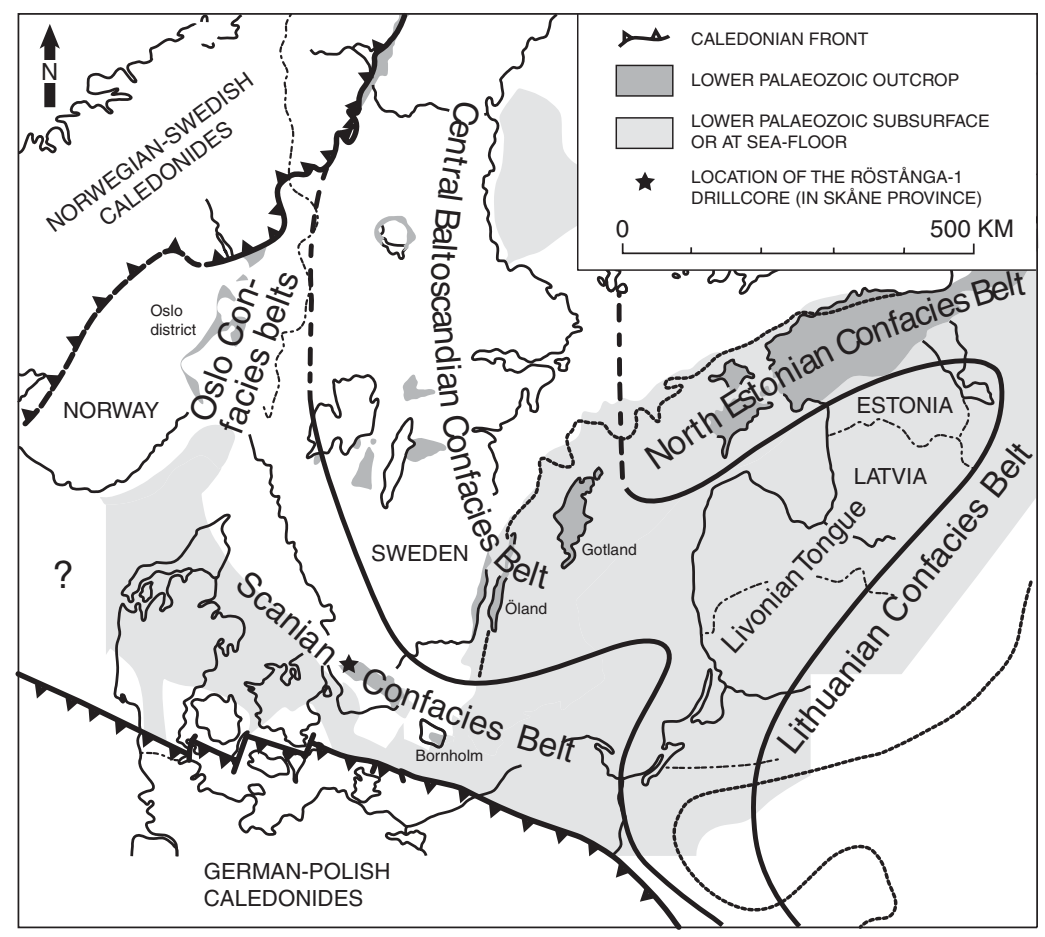

Fig. 1. Palaeogeography of Baltoscandia and distribution of Palaeozoic strata in the region. The Late Ordovician depth zonation of the Baltoscandian basin is shown (confacies belts of Jaanusson 1995) as well as the location of the Röstånga-1 drillcore in the shale-dominated Scanian Confacies Belt.

For the palynological analysis, a total of 21 samples were collected from the Fjäcka Shale, the Lindegård Mudstone and the Kallholn Formation, corresponding to the interval between 91.0 and $49.0 \mathrm{~m}$ (Fig. 2). The samples were processed palynologically at Global Geolab Limited in Canada, according to standard palynological processing methods. The reference for colour measurements for assessing the thermal alteration index (TAI) is the colour standards of Philips Petroleum Company. The core and the palynological slides with illustrated specimens (numbered with the prefix LO) are housed at the Department of Geology, Lund University.

\section{Stratigraphy and lithologies}

The Skagen Formation in the Röstånga-1 drillcore consists of a grey to greenish skeletal limestone, rich in trilobite fragments, alternating with calcareous mudstone. Regionally, it shows a substantial lateral variation in thickness, and it has been suggested that this unit reflects a eustatic sea level fall (Bergström et al. 1997). In the Röstånga-1 core, a relative shallowing of sea-level at this level is supported by facies and the overall stratigraphic development, and the presence of a discontinuity surface with angular- to round-shaped solution structures at the top of the Skagen Limestone (Fig. 3). This irregular surface most likely correlates with the conglomerate previously reported at the top of the Skagen Limestone in the Borenshult core, Östergötland (Bergström et al. 2011), the unconformable boundary at the top of the Kullsberg mud mounds in the Siljan district (Calner et al. 2010a), and with the sequence boundary reported at the Keila-Oandu stage boundary in the East Baltic area by Ainsaar et al. (2004, p. 122-123; for a discussion of Katian sea-level, see Calner et al. 2010a). Accordingly, this disconformity is associated with substantial erosion and a hiatus not only in the northern Estonian shelf sections but also across large parts of Baltoscandia.
The presence of the Skagen Limestone and the associated discontinuity surface in the core show that this early Katian shallowing resulted in carbonate deposition even along the margins of the continent where the depositional environment usually was much deeper. There is, however, no macroscopical evidence for subaerial exposure at this level in the core, and the discontinuity surface is inferably associated with submarine dissolution that took place after the maximum lowstand due to sediment starvation and transgression. This transgression is marked by the overlying Mossen Formation that constitutes glauconite-rich limestone and strongly bioturbated grey mudstone. The basal portion of the overlying Fjäcka Shale is generally laminated suggesting low oxygen levels and a prolonged transgression. This unit is a basin-wide marker bed that locally caps the truncated Kullsberg mud mounds in the Siljan district (Calner et al. 2010a) or a coeval regional palaeokarst surface elsewhere in southern Sweden and the East Baltic area (Calner et al. 2010b).

The contact between the Lindegard Mudstone and the Kallholn Formation is gradational from light grey mudstone to dark grey and graptolitic mudstone and shale, and the boundary is arbitrarily placed at a depth of ca. $56 \mathrm{~m}$ at the top of the Metabolograptus persculptus graptolite Zone, recognized in the core by Koren' et al. (2003) and Maletz et al. (2014). The Kallholn Formation represents a new transgression, most likely associated with a late Hirnantian deglaciation.

\section{Palynology}

\section{Cryptospores}

The palynological assemblages are dominated by marine microfossils but we have here for the first time also identified spores from land plants represented by cryptophytes (sensu Edwards et al. 2014). The presence of a sparse but wellpreserved cryptospore assemblage including Tetrahedraletes 
Fig. 2. Lithological succession, stratigraphic subdivision and sample levels of the Röstånga-1 drillcore. Based on Bergström et al. (1999, 2014), Pålsson (2002), Koren' et al. (2003) and Maletz et al. (2014). SB, sequence boundary. Abbreviations of stratigraphic names: SuF, Sularp Formation; SkF, Skagen Formation; MF, Mossen Formation.

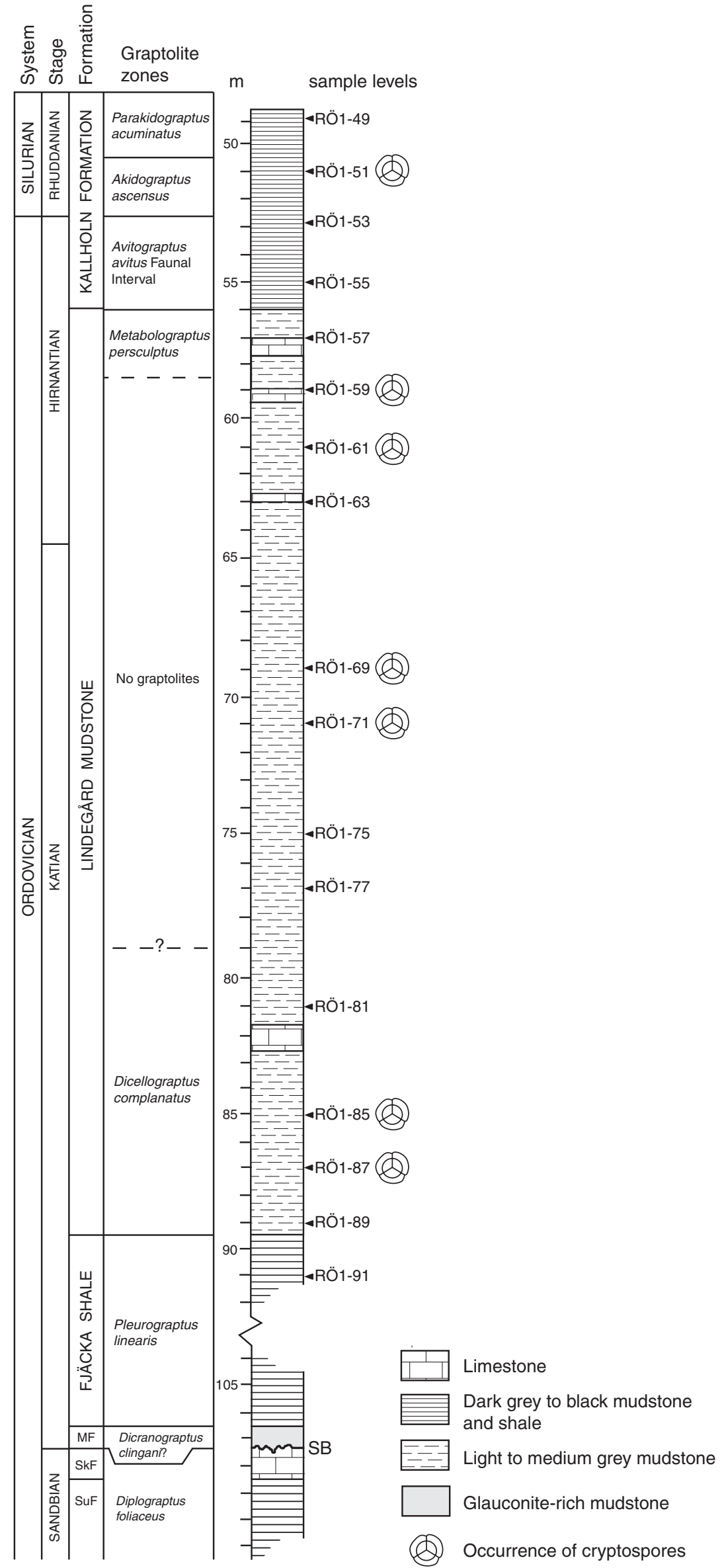




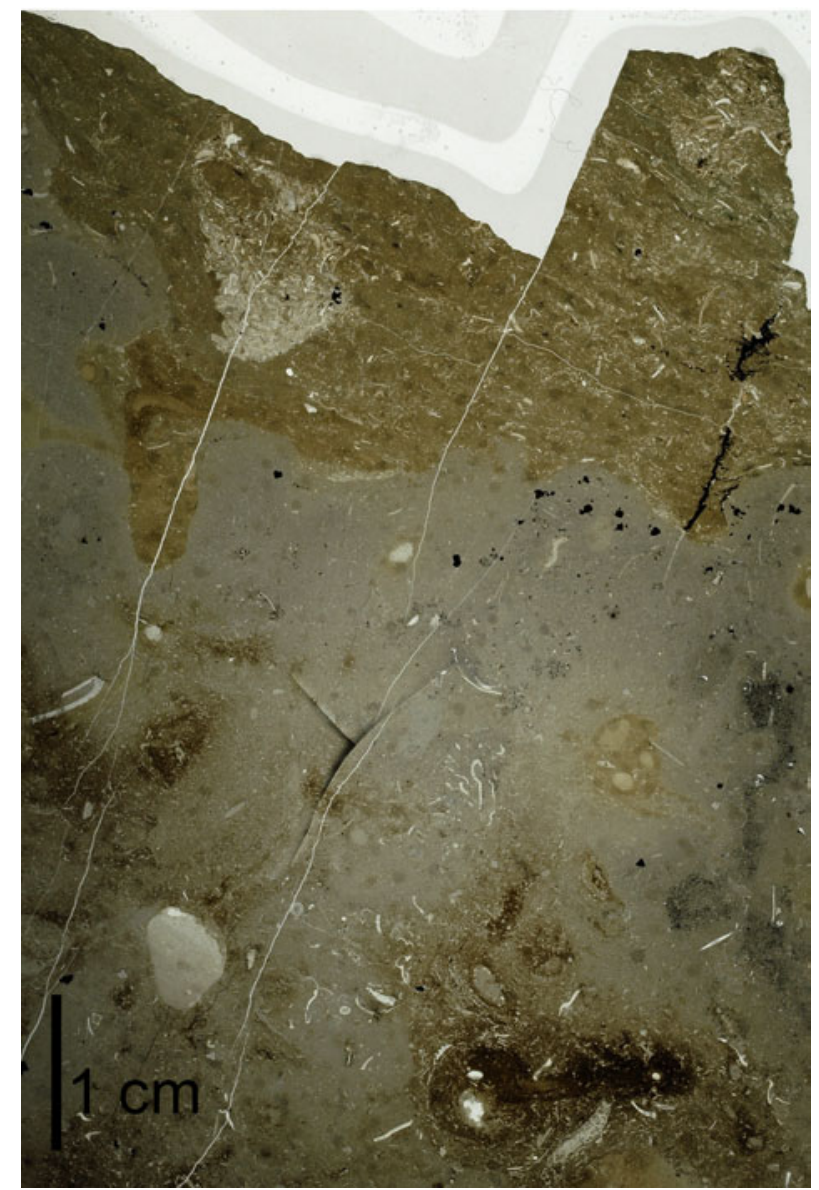

Fig. 3. Thin section of the drillcore showing the disconformity and solution structures at the top of the Skagen Limestone. Note brownish infill with fine skeletal hash of the Mossen Formation. Photo courtesy: Oliver Lehnert.

medinensis (Fig. 4L,N,O), Tetrahedraletes grayii (Fig. 4M) and Pseudodyadospora sp. possibly provides the oldest evidence of early land plants in Baltica and definitely the oldest spore record from the Lower Palaeozoic of Sweden.

The crypotospores of this study were recovered from the Lindegård Mudstone at the following core depths: 87.0, 85.0, 71.0, 69.0, 61.0, 59.0 and $51.0 \mathrm{~m}$ (Fig. 2). The oldest record is just above the appearance of the early Katian graptolite species Dicellograptus complanatus, recognized in the core by Pålsson (2002; i.e. Ka4 Stage Slice of Bergström et al. 2009). The presence of cryptospores in the Röstanga-1 core shows that land plants had migrated to Baltica by at least the Late Ordovician.

T. medinensis, T. grayii and Pseudodyadospora sp., have been reported globally from coeval assemblages, possibly indicating homogeneous land plant assemblages that tolerated a wide range of climatic conditions (e.g. Vecoli et al. 2011).

\section{Acritarchs}

Three well-preserved and diverse acritarch assemblages were recovered. The assemblage recovered from the upper Fjäcka Shale (lower Katian; sample RÖ1-91) and the lower-middle
Lindegård Mudstone (lower-upper Katian; samples RÖ1-89 to RÖ1-75) is characterized by the occurrence of the key acritarchs Baltisphaeridium spp., Buedingiisphaeridium balticum and Orthosphaeridium spp. The record of diagnostic Early-Middle Ordovician acritarchs, e.g. Striatotheca (Fig. 4D), Coryphidium (Fig. 4H) and Acanthodiacrodium-Coryphidium (Fig. 4J), indicates that reworking of older sediments has occurred, possibly suggesting an Avalonian detrital sediment provenance in a foreland basin system. This assemblage is possibly coeval with assemblages described from Anticosti Island, Québec, Canada (Jacobson \& Achab 1985), Jordan (Keegan et al. 1990), Iran (Ghavidel-Syooki 1997) and Estonia (Delabroye et al. 2011a).

The assemblage from the upper Katian-Hirnantian portion of the Lindegård Mudstone (samples RÖ1-69 to RÖ1-57) is characterized by the occurrence of long-ranging acritarchs [e.g. Veryhachium (Fig. 4A,B), Micrhystridium (Fig. 4I) and Leiosphaeridia] and by the appearance of several taxa with Silurian affinity, e.g. Ammonidium spp. (Fig. 4G), Diexallophasis denticulata (Fig. 4F) and Tylotopalla sp. (Fig. 4E). This assemblage seems to mark a global event, possibly related to the initial stage of the Hirnantian glaciation with a major palaeoenvironmental stress (e.g. Delabroye et al. 2011b). The age of this assemblage is probably comparable to assemblages described from northern Gondwana (Vecoli \& Le Hérissé 2004), southern Turkey (Paris et al. 2007), Estonia (Delabroye et al. 2011a) and Anticosti Island, Québec, Canada (Delabroye et al. 2011b).

The assemblage from the lower Kallholn Formation (uppermost Hirnantian-lower Rhuddanian; samples RÖ1-55 to RÖ149) is characterized by the presence of sphaeromorph acritarchs together with a relatively high abundance of graptolites and rare cryptospores. Acritarchs are scarce throughout this interval, which agrees with palynological studies from coeval strata in other parts of the world. The acritarch assemblage from the Kallholn Formation may also in part be correlated with assemblages from acritarch zone 'AS4' in the Valga-10 core, southern Estonia (Delabroye et al. 2011a). It is also comparable to assemblages described from Jordan (Armstrong et al. 2009).

The acritarchs recovered from the Röstånga-1 drillcore are brownish black in colour, indicating a TAI of 4, which is considered post-mature with respect to oil generation. The high thermal maturity is probably the result of a combination of relatively deep burial in a foreland basin setting and extensive magmatic activity during the early Permian.

\section{Conclusions}

Palynological studies through the Katian-lowermost Llandovery succession of the Röstånga-1 core, southern Sweden, have been performed. The palynological assemblages are strongly dominated by marine microfossils and reveal an off-shore depositional environment. The presence of cryptospores, representing the earliest evidence of land plants in Sweden and possibly in Baltica, provides additional evidence for the timing of terrestrialization of plants and the spreading patterns of early land plants. The occurrence of older, Early-Middle Ordovician acritarchs indicates that reworking has occurred, possibly suggesting an Avalonian detrital sediment provenance in a foreland basin system. 


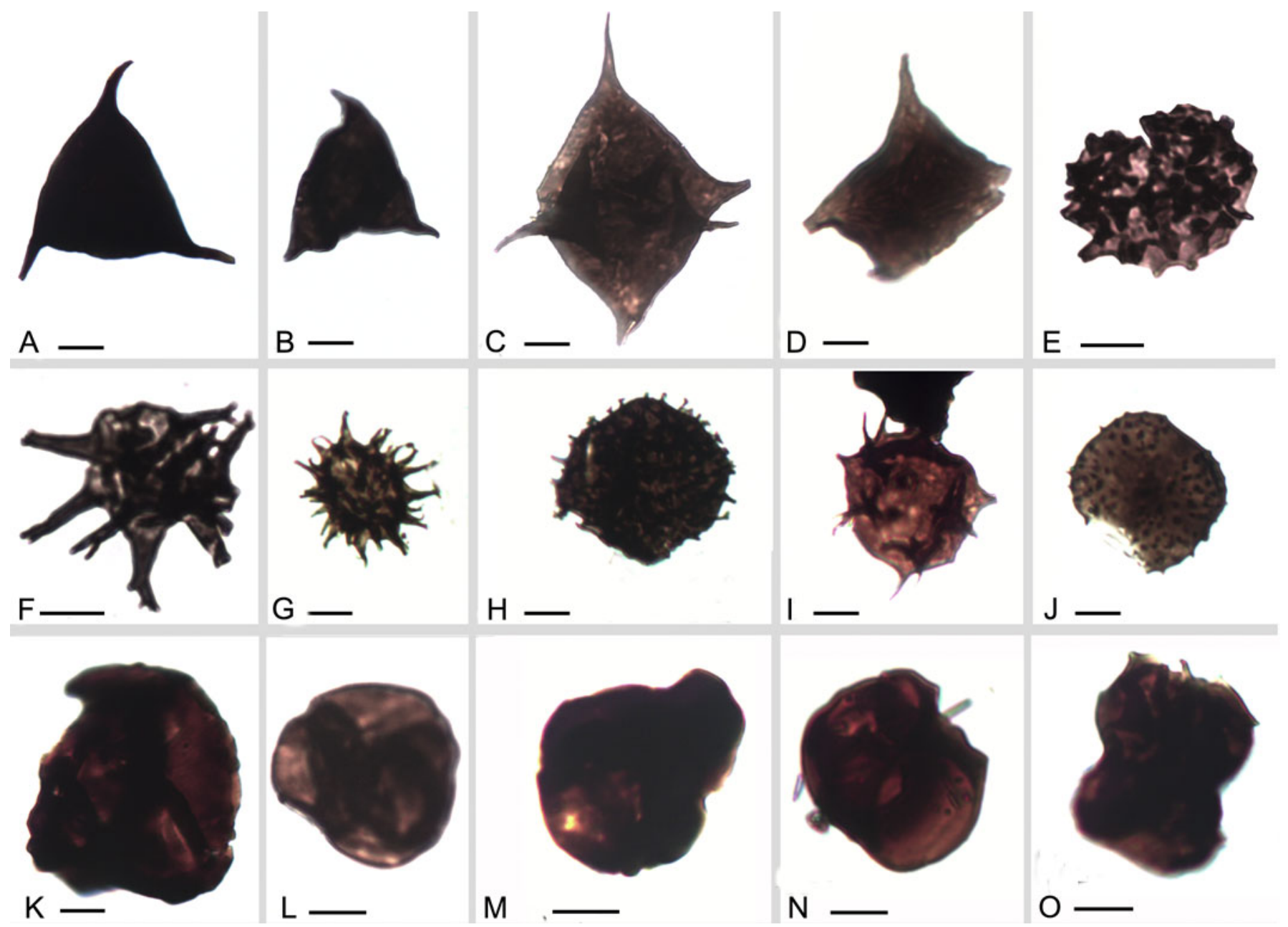

Fig. 4. Light micrographs of representative palynomorphs from the studied samples, scale bars $=10 \mu \mathrm{m}$. Taxa, sample number, England Finder Reference (EFR) and LO numbers. A. Veryhachium sp., RÖ1-69, EFR: M29/3, middle Lindegård Mudstone, 69.0 m, LO11883 t. B. Veryhachium sp., RÖ1-69, EFR: U27, middle Lindegård Mudstone, 69.0 m, LO11884 t. C. Veryhachium? sp., RÖ1-59, EFR: G10, upper Lindegård Mudstone, 59.0 m, LO11885 t. D. Striatotheca sp., RÖ1-77, EFR: X40/1, middle Lindegård Mudstone, 77.0 m, LO11886t. E. Tylotopalla sp., RÖ1-69, EFR: H41, middle Lindegård Mudstone, 69.0 m, LO11887 t. F. Diexallophasis denticulata (Stockmans \& Willière) Loeblich, RO1-69, EFR: T44, middle Lindegård Mudstone, 69.0 m, LO11888 t. G. Ammonidium sp., RÖ1-69, EFR: V47, middle Lindegård Mudstone, $69.0 \mathrm{~m}$, LO11889t. H. Coryphidium sp., RÖ1-77, EFR: L34/3, middle Lindegård Mudstone, 77.0 m, LO11890 t. I. Micrhystridium sp., RÖ1-71, EFR-D24, middle Lindegård Mudstone, $71.0 \mathrm{~m}$, LO11891 t. J. Acanthodiacrodium-Coryphidium, RÖ1-77, EFR: M38, middle Lindegård Mudstone, 77.0 m, LO11892t. K. Cryptospore gen. et sp., indet, RÖ1-51, EFR: W13, Kallholn Formation, 51.0 m, lower Rhuddanian Stage (Llandovery), Akidograptus ascensus Zone, LO11893 t. L. Tetrahedraletes medinensis (Strother \& Traverse) Wellman \& Richardson, RÖ1-87, EFR: O32, lower Lindegård Mudstone, Dicellograptus complanatus Zone, 87.0 m, LO11894 t. M. Tetrahedraletes grayii Strother, RÖ1-71, EFR: U13/2, middle Lindegård Mudstone, 71.0 m, LO11895 t. N. T. medinensis (Strother \& Traverse) Wellman \& Richardson, RÖ1-61, EFR: F19, upper Lindegård Mudstone, 61.0 m, LO11896 t. O. T. medinensis (Strother \& Traverse) Wellman \& Richardson, RÖ1-69, EFR: V41/1, middle Lindegård Mudstone, $69.0 \mathrm{~m}, \mathrm{LO} 11897 \mathrm{t}$.

Acknowledgements - The results form part of ASB's master thesis at Lund University. The studies were supported by European grant (L020901652) to ASB. Claudia Rubinstein is acknowledged for discussions concerning the acritarch and spore taxonomy. We further thank Axel Munnecke and Thomas Servais for reviewing the manuscript and suggesting improvements. This research was further supported by the Swedish Research Council through grant LUCCI (Lund University Carbon Cycle Interactions) to K. Mehlqvist and V. Vajda. M. Calner acknowledges support from the Swedish Research Council. This paper is a contribution to the IGCP Project 591 (The Early to Middle Palaeozoic Revolution).

\section{References}

Ainsaar, L., Meidla, T. \& Martma, T., 2004: The Middle Caradoc facies and faunal turnover in the Late Ordovician Baltoscandian palaeobasin. Palaeogeography, Palaeoclimatology, Palaeoecology 210, 119-133.

Armstrong, H.A., Abbott, G.D., Turner, B.R., Makhlouf, I.M., Muhammad, A. B., Pedentchouk, N. \& Peters, H., 2009: Black shale deposition in an Upper Ordovician-Silurian permanently stratified, peri-glacial basin, southern Jordan. Palaeogeography, Palaeoclimatology, Palaeoecology 273, 368-377.
Bergström, S.M., Calner, M., Lehnert, O. \& Noor, A., 2011: A new upper Middle Ordovician-Lower Silurian drillcore standard succession from Borenshult in Östergötland, southern Sweden. 1. Stratigraphical review with regional comparisons. GFF 133, 149-171.

Bergström, S.M., Chen, X., Gutiérrez-Marco, J.C. \& Dronov, A., 2009: The new chronostratigraphic classification of the Ordovician system and its relations to major regional series and stages and to $\delta^{13} \mathrm{C}$ chemostratigraphy. Lethaia 42 , $97-107$.

Bergström, S.M., Eriksson, M.E., Young, S.A., Ahlberg, P. \& Schmitz, B., 2014 Hirnantian (latest Ordovician) $\delta{ }^{13} \mathrm{C}$ chemostratigraphy in southern Sweden and globally: a refined integration with the graptolite and conodont zone successions. GFF. http://dx.doi.org/10.1080/11035897.2013.851734

Bergström, S.M., Huff, W.D., Kolata, D.R., Yost, D.A. \& Hart, C., 1997: A unique Middle Ordovician K-bentonite bed succession at Röstånga, S. Sweden. GFF 119, 231-244.

Bergström, S.M., Huff, W.D., Koren', T., Larsson, K., Ahlberg, P. \& Kolata, D. R., 1999: The 1997 core drilling through Ordovician and Silurian strata at 
Röstånga, S. Sweden: preliminary stratigraphic assessment and regional comparison. GFF 121, 127-135.

Calner, M., Ahlberg, P., Lehnert, O. \& Erlström, M. (eds.), 2013: The Lower Palaeozoic of southern Sweden and the Oslo Region, Norway. Field Guide for the 3rd Annual Meeting of the IGCP project 591. Sveriges geologiska undersökning Rapporter och meddelanden 133, 1-96.

Calner, M., Lehnert, O. \& Joachimski, M., 2010a: Carbonate mud mounds, conglomerates, and sea-level history in the Katian (Upper Ordovician) of central Sweden. Facies 56, 157-172.

Calner, M., Lehnert, O. \& Nõlvak, J., 2010b: Palaeokarst evidence for widespread regression and subaerial exposure in the middle Katian (Upper Ordovician) of Baltoscandia: significance for global climate. Palaeogeography, Palaeoclimatology, Palaeoecology 296, 235-247.

Delabroye, A., Munnecke, A., Vecoli, M., Copper, P., Tribovillard, N., Joachimski, M.M., Desrochers, A. \& Servais, T., 2011b: Phytoplankton dynamics across the Ordovician/Silurian boundary at low palaeolatitudes: correlations with carbon isotopic and glacial events. Palaeogeography, Palaeoclimatology, Palaeoecology 312, 79-97.

Delabroye, A., Vecoli, M., Hints, O. \& Servais, T., 2011a: Acritarchs from the Ordovician-Silurian boundary beds of the Valga-10 drill core, southern Estonia (Baltica) and their stratigraphical and palaeobiogeographical implications. Palynology 35, 4-45.

Edwards, D., Morris, J.L., Richardson, J.B. \& Kenrick, P., 2014: Cryptospores and cryptophytes reveal hidden diversity in early land floras. New Phytologist. doi: 101111/nph. 12645.

Erlström, M., Deeks, N., Sivhed, U. \& Thomas, S., 1997: Structure and evolution of the Tornquist Zone and adjacent sedimentary basins in Scania and the southern Baltic Sea area. Tectonophysics 271, 191-215.

Ghavidel-Syooki, M., 1997: Acritarch biostratigraphy of the Palaeozoic rock units in the Zagros Basin, Southern Iran. In O. Fatka \& T. Servais (eds.): Acritarcha in Praha 1996. Acta Universitatis Carolinae, Geologica 40, 385411.

Gray, J., Laufeld, S. \& Boucot, A.J., 1974: Silurian trilete spores and spore tetrads from Gotland: their implications for land plant evolution. Science 185, $260-263$.

Hagström, J., 1997: Land-derived palynomorphs from the Silurian of Gotland, Sweden. GFF 119, 301-316.

Hagström, J. \& Mehlqvist, K., 2012: The dawn of terrestrial ecosystems on Baltica: first report on land plant remains and arthropod coprolites from the upper Silurian of Gotland, Sweden. Palaeogeography, Palaeoclimatology and Palaeoecology 317-318, 162-170.

Jaanusson, V., 1995: Confacies differentiation and upper Middle Ordovician corelation in the Baltoscandian Basin. Proceedings of the Estonian Academy of Sciences, Geology 44, 73-86.

Jacobson, S.R. \& Achab, A., 1985: A critarch biostratigraphy of the Dicellograptus complanatus graptolite Zone from the Vauréal Formation (Ashgillian), Anticosti Island, Quebec, Canada. Palynology 9, 165-198.
Keegan, J.B., Rasul, S.M. \& Shaheen, Y., 1990: Palynostratigraphy of the Lower Palaeozoic, Cambrian to Silurian, sediments of the Hashemite Kingdom of Jordan. Review of Palaeobotany and Palynology 66, 167-180.

Koren', T.N., Ahlberg, P. \& Nielsen, A.T., 2003: The post-persculptus and preascensus graptolite fauna in Scania, south-western Sweden: Ordovician or Silurian? In G. Ortega \& G.F. Acenolaza (eds.): Proceeding of the 7th International Graptolite Conference \& Field Meeting of the Subcommission on Silurian Stratigraphy. Instituto Superior de Correlacion Geologica (INSUGEO), Tucumán, Serie Correlacion Geologica 18, 133-138.

Le Hérissé, A., Al-Ruwaili, M., Miller, M. \& Vecoli, M., 2007: Environmental changes reflected by palynomorphs in the early Middle Ordovician Hanadir Member of the Qasim Formation, Saudi Arabia. Revue de Micropaléontologie $50,3-16$.

Maletz, J., Ahlberg, P., Suyarkova, A. \& Loydell, D.K., 2014: Silurian graptolite biostratigraphy of the Röstånga-1 drill core, Scania - a standard for southern Scandinavia. GFF 136. http://dx.doi.org/10.1080/11035897.2013.865665

Mehlqvist, K., Larsson, K. \& Vajda, V., 2014: Linking upper Silurian terrestrial and marine successions - palynological study from Skane, Sweden. Review of Palaeobotany and Palynology (in press). http://dx.doi.org/10.1016/ j.revpalbo.2013.12.001

Mehlqvist, K., Vajda, V. \& Steemans, P., 2012: Early land plant spore assemblages from the late Silurian of Skåne, Sweden. GFF 134, 133-144.

Pålsson, C., 2002: Upper Ordovician graptolites and biostratigraphy of the Röstănga 1 core, Scania, S. Sweden. Bulletin of the Geological Society of Denmark 49, 9-23.

Paris, F., Le Hérissé, A., Monod, O., Kozlu, H., Ghienne, J.-F., Dean, W.T., Vecoli, M. \& Günay, Y., 2007: Ordovician chitinozoans and acritarchs from southern and southeastern Turkey. Revue de Micropaléontologie 50, 81-107.

Rubinstein, C.V., Gerrienne, P., de la Puente, G.S., Astini, R.A. \& Steemans, P., 2010: Early Middle Ordovician evidence for land plants in Argentina (eastern Gondwana). New Phytologist 188, 365-369.

Strother, P.K., Al-Hajri, S. \& Traverse, A., 1996: New evidence for land plants from the lower Middle Ordovician of Saudi Arabia. Geology 24, 55-58.

Vavrdová, M., 1990: Early Ordovician acritarchs from the locality Myto near Rokycany (late Arenig, Czecholovakia). Casopis pro Mineralogii a Geologii $35,239-250$.

Vecoli, M., Delabroye, A., Spina, A. \& Hints, O., 2011: Cryptospore assemblages from Upper Ordovician (Katian-Hirnantian) strata of Anticosti Island, Québec, Canada, and Estonia: palaeophytogeographic and palaeoclimatic implications. Review of Palaeobotany and Palynology 166, 76-93.

Vecoli, M. \& Le Hérissé, A., 2004: Biostratigraphy, taxonomic diversity, and patterns of morphological evolution of Ordovician acritarchs (organic-walled microphytoplankton) from the northern Gondwana margin in relation to palaeoclimatic and palaeogeographic changes. Earth-Science Reviews 67, 267-311.

Wellman, C.H., Osterloff, P.L. \& Mohiuddin, U., 2003: Fragments of the earliest land plants. Nature 425, 282-285. 